\title{
ENDOTHELIAL DYSFUNCTION IN COVID-19 PATIENTS AND CLINICAL APPLICATION OF LASER THERAPY
}

Kochetkov $\mathrm{AV}^{1,2} \otimes$, Ponomareva NYu², Kadnikova NG², Mitkovskij VG ${ }^{1,2}$, Yampolskaya EN², Lazarev V²

${ }^{1}$ Academy of Postgraduate Education FNSC FMBA of Russia, Moscow, Russia

${ }^{2}$ Central Clinical Hospital for the Rehabilitation of FMBA of Russia, Solnechnogorsk District, Moscow Region, Russia

This review covers the published papers describing endothelial dysfunction pathogenesis and molecular mechanisms behind the effect of low-level laser therapy on regulation of the said pathogenesis. Herein, we present the current experience of using laser therapy to prevent development of endothelial dysfunction in the context of post-COVID-19 rehabilitation, as well as the accumulated data on the methods of combination of external or intravenous laser blood therapy and influence on the immunocompetent. We provide justification for practicing personalized approach at various stages of post-COVID-19 rehabilitation and treatment. The basis allowing greater efficacy of post-COVID-19 rehabilitation, including protocols making use of laser therapy, is the analysis of single-nucleotide polymorphisms of genes that determine adaptation processes, peculiarities of the immune response to infectious pathogens, predisposition to the development of respiratory distress syndrome, severe pneumonia, sepsis, multiple organ failure, development of endothelial dysfunction, thrombotic complications, the analysis that allows identification of patients running higher risk of critical conditions.

Keywords: COVID-19, endothelial dysfunction, rehabilitation treatment, laser therapy, personalized approach, genotyping

Author contribution: AV Kochetkov — idea, data analysis and interpretation; NYu Ponomareva — literature analysis, manuscript drafting; NG Kadnikova — laser therapy technique application, data collection; VG Mitkovskij — research organization task setting; EN Yampolskaya — research results analysis and interpretation; W Lazarev - selection of patients for application of the technique, analysis of the results.

$\square$ Correspondence should be addressed: Andrey V. Kochetkov

Volokolamskoe shosse, 91, Moscow, 125371; kotchetkov@inbox.ru

Received: 09.11.2020 Accepted: 24.11.2020 Published online: 18.12.2020

DOI: $10.47183 /$ mes.2020.024

\section{ЭНДОТЕЛИАЛЬНАЯ ДИСФУНКЦИЯ У БОЛЬНЫХ COVID-19 И КЛИНИЧЕСКОЕ ПРИМЕНЕНИЕ ЛАЗЕРНОЙ ТЕРАПИИ}

А. В. Кочетков ${ }^{1,2} \bowtie$, Н. Ю. Пономарева ${ }^{2}$ Н. Г. Кадникова ${ }^{2}$, В. Г. Митьковский ${ }^{1,2}$, Е. Н. Ямпольская², В. В. Лазарев²

${ }_{1}^{1}$ Академия постдипломного образования Федеральный научно-клинический центр Федерального медико-биологического агентства, Москва, Россия 2 Центральная клиническая больница восстановительного лечения Федерального медико-биологического агентства, Солнечногорский район, Московская обл., Россия

В обзоре литературы по патогенезу развития дисфункции эндотелия и молекулярным механизмам влияния низкоинтенсивного лазерного излучения на его регуляцию представлены актуальный опыт применения лазерной терапии для предотвращения развития эндотелиальной дисфункции в реабилитации больных COVID-19, методы сочетания наружного или внутривенного лазерного освечивания крови и воздействия на иммунокомпетентные органы. Обоснован персонализированный подход к лечению и просилактике на различных этапах реабилитации пациентов, перенесших COVID-19. Анализ однонуклеотидных полиморфизмов генов, детерминирующих процессы адаптации, особенности иммунного ответа на инфекционные возбудители, предрасположенность к развитию респираторного дистресс-синдрома, тяжелому течению пневмонии, сепсиса, полиорганной недостаточности; развитию эндотелиальной дисфункции, тромботическим осложнениям для выявления пациентов с повышенным риском критических состояний является основой повышения эффективности восстановительного лечения таких больных, в том числе с применением методов лазерной терапии.

Ключевые слова: COVID-19, эндотелиальная дисфункция, восстановительное лечение, лазерная терапия, персонифицированный подход, генотипирование

Вклад авторов: А. В. Кочетков - идея, анализ и трактовка данных; Н. Ю. Пономарева - анализ литературы, подготовка черновика рукописи; Н. Г. Кадникова - применение методики лазерной терапии, сбор данных; В. Г. Митьковский - постановка задачи организации исследования; Е. Н. Ямпольская - анализ и трактовка результатов исследования; В. В. Лазарев - отбор пациентов для применения методики, анализ результатов.

$\bowtie$ Для корреспонденции: Андрей Васильевич Кочетков

Волоколамское шоссе, д. 91, г. Москва, 125371; kotchetkov@inbox.ru

Статья получена: 09.11.2020 Статья принята к печати: 24.11.2020 Опубликована онлайн: 18.12.2020

DOI: $10.47183 /$ mes.2020.024

The global COVID-19 pandemic caused by the SARS-CoV-2 coronavirus is a challenge for the entire mankind, but the first to search for solutions thereto are scientists and doctors that are tasked with finding ways to curb incidence, effectively treat and rehabilitate COVID-19 patients and minimize the associated complications and mortality.

One of the many features of COVID-19 is the pronounced non-specificity of the observed pathological processes and its capacity to damage both organs and tissues and functional regulatory systems. At the same time, development of endothelial dysfunction can be named a factor that largely unites various disorders. There is an opinion gaining popularity that vascular endothelial damage is the cornerstone of organ dysfunction in severe SARS-CoV-2 infection cases [1].
The patients that died from respiratory failure resulting from COVID-19 had diffuse alveolar injury with perivascular T-cell infiltration as a specific histological pattern registered in the peripheral lung. The lungs of these patients have distinctive vascular features: severe endothelial damage associated with intracellular presence of the virus and fragments of destroyed cell membranes. Histological analysis of pulmonary vessels of COVID-19 patients revealed widespread thrombosis and microangiopathy. COVID-19 patients had alveolar capillary micro clots 9 times more often than influenza patients $(p<0.001)$. All this indicates that the disease also translates into a severe endothelial dysfunction [2].

Endothelial dysfunction (EnD) - a complex multifaceted process typically seen in the context of cardiovascular, 
metabolic and immune disorders - is a current and serious challenge for clinical practitioners, even when considered outside of connection to COVID-19 [3]. And with a developing viral infection in the background, exploring the means to prevent this pathology is of paramount importance.

Endothelium is a cardiovascular endocrine organ that, in critical situations, enables communication between blood and tissues [4]. It acts as a barrier between the blood and the vascular wall, helps adaptation to changing environmental conditions through local regulation of vascular tone, vascular wall integrity protection etc. Normally, endothelial cells, following alterations in blood flow rate, exposure to mediators or neurohormones, react by increasing the synthesis of substances that cause relaxation of the vascular wall's smooth muscle cells (nitric oxide (NO) and other relaxants). They also work to prevent thrombogenesis by blocking platelet aggregation, oxidating low density lipoproteins, expressing adhesion molecules, "sticking" monocytes and platelets to the vascular wall, producing endothelin etc. Compensatory mechanisms are activated under the influence of a damaging factor. In case of prolonged exposure to such a factor (hypoxia, intoxication, inflammation, hemodynamic overload, etc.), compensation fades and a pathological process develops. Endothelial dysfunction is an imbalance between biologically active substances synthesized by endothelial cells (potentially protective NO, endothelial hyperpolarization factor, prostaglandins) and damaging substances (endothelin-I, thromboxane A2, superoxide anion etc.) [5].

It is the genotype that shapes all these normal and pathological molecular mechanisms of endothelium's adaptive response to normal or excessive influences. Currently, there are over 1500 genes established to have an association with multifactorial human diseases.

The human genome investigation efforts in the context of the Human Genome Project, Hap Map project, The 1000 Genomes projects, The SNP Consortium, have revealed mutations and single nucleotide polymorphisms (SNP) in genes encoding protein molecules of the body's regulatory systems. Their associations with various pathologies were either confirmed or refuted [6-9].

For example, the public Online Mendelian Inheritance in Man database (OMIM) [10] and the single nucleotide polymorphisms database contain more than 3.5 million SNP markers [11].

One of the studies investigating the significance of polymorphism of various genes considered possible contributors to the development of cardiovascular diseases (CVD) identified 105 genes that most likely support pathophysiology of CVD [12]. The researchers focus on genes that determine endothelium's properties, its role in the development of local vasospasm/ vasodilation, hemostasis, inflammation, atherosclerosis, angiogenesis, etc [13-14].

Long before the COVID-19 pandemic, significant individual characteristics of critical conditions observed dynamically triggered the analysis of the results of geno-phenotypic examinations of IC patients [15-19]. These studies presented comorbid conditions gene diagnostics, identified SNP markers associated with an increased risk of community-acquired and nosocomial pneumonia, risk of development of an acute respiratory distress syndrome, CVD-related thrombotic complications. The results of the analysis of identified gene polymorphisms the products of which shape regulation (hemostasis, renin-angiotensin system regulation, immune system regulation, i.e. individual response to infectious pathogens and production of cytokines, drug metabolism) provide justification to screening patients running a high risk of development of life-threatening conditions. Such patients need non-standard treatment approaches in critical situations.

Personalized approach is a strategy popular at various stages of rehabilitation. In particular, patients in cardio- and neurorehabilitation undergo genotyping enabled by various SNP panels [20-25]. In clinical practice, molecular markers of individual susceptibility to various patterns of CVD development (the most important of which is endothelial dysfunction) allow predicting sudden death of a patient or the development of catastrophic multiple organ complications, as well as choosing the most effective therapies, which may be pharmacotherapy and non-drug methods [26-27], including laser therapy.

It was observed that patients with different phenotypes respond to laser therapy differently. In particular, low level laser therapy (LLLT) was more effective in patients that exhibited domination of reactions of the sympathetic nervous system than in those whose parasympathetic responses were stronger [28]. The peculiarities of the endothelial function were found to be behind this difference. The said function is genetically determined by the cooperation of gene regulatory networks [26-27]; it needs to be studied further, same as the collation of geno- and phenotypical characteristics and individual responses to various therapies.

Concomitant diseases can synergistically activate pathophysiological pathways. Thus, inflammation activates vascular pathology through pro-inflammatory cytokines, endothelin-1 and nitric oxide, which contributes to long-term damage to fatty acids, proteins, DNA, and mitochondria. Dysfunctional energy metabolism (impaired production of mitochondrial ATP, the formation of amyloid- $\beta$ ), development of endothelial dysfunction and violation of the blood-brain barrier lead to the cerebral blood flow reduction and chronic cerebral hypoperfusion with oxygen and nutrient deficiency, metabolic and synaptic disorders, neurodegeneration and white matter atrophy, cognitive dysfunction and development of Alzheimer's disease [29]. Identification and assessment of the entire complex of pathogenetic mechanisms driving inflammation form basis for targeted therapies designed to remedy the reduced cerebral blood flow and hypometabolism.

\section{Molecular-cellular and physiological mechanisms of vascular homeostasis regulation}

The key manifestations of EnD are abnormal bioavailability of nitric oxide (NO), the main vasodilator, which results from suppression of endothelial NO synthase (NOS), with the NO synthesis decreasing consequently [30]. Under normal physiological conditions, there is a balance between vasoconstrictors secreted by the endothelium and vasodilators. Any violation of this balance leads to a local spasm and vascular tone growth. As a result, the compensatory capacity of endothelium deteriorates gradually, which translates into breakdown of a rather complex regulation of the natural vascular bed expansion and shrinking mechanisms [13]. Endothelium plays a key role in maintaining vascular homeostasis since it releases biologically active substances (Table 1), but is also susceptible to the effects of external regulators [31-33]:

- mast cells that release heparin and histamine;

- platelets containing vascular endothelial growth factors and blood coagulation factors, etc;

- hormones and neuropeptides (adrenaline, acetylcholine, histamine, bradykinin, etc).

Despite the fact that the regulation mechanisms are known (see Table 1), the ways to remedy endothelial dysfunction pharmacologically require further comprehensive study and 
Table 1. Physiologically active substances, regulators of the circulatory system, synthesized in the endothelium

\begin{tabular}{|c|c|}
\hline \multicolumn{2}{|c|}{ Vascular wall tone regulators } \\
\hline Vasoconstrictors & Vasodilators \\
\hline $\begin{array}{c}\text { Endothelin I-II } \\
\text { Angiotensin II } \\
\text { Thromboxane }\left(\mathrm{TXA}_{2}\right) \\
\text { Prostaglandins } \mathrm{H}_{2} \text { and } \mathrm{G}_{2}\end{array}$ & $\begin{array}{c}\text { Nitric oxide }(\mathrm{NO}) \\
\text { Prostaglandin } \mathrm{E}_{2}\left(\mathrm{PGE}_{2}\right) \\
\text { Endothelial hyperpolarizing factor (EDHF) } \\
\text { Bradykinin } \\
\text { C-natriuretic peptide Adrenomedullin } \\
\text { Endothelin III }\end{array}$ \\
\hline \multicolumn{2}{|c|}{ Regulators of hemostasis and antithrombosis } \\
\hline Prothrombogenic factors & Antithrombogenic factors \\
\hline $\begin{array}{l}\text { Platelet-derived growth factor (PDGF) tissue plasminogen activator inhibitor } \\
\text { (PAI-I) } \\
\qquad \begin{array}{c}\text { Von Willebrand factor (coagulation factor VIII) } \\
\text { Angiotensin IV } \\
\text { Endothelin I }\end{array}\end{array}$ & $\begin{array}{c}\mathrm{NO} \\
\text { Tissue plasminogen activator (t-PA) } \\
\text { Prostacyclin }\left(\mathrm{PGI}_{2}\right)\end{array}$ \\
\hline \multicolumn{2}{|c|}{ Leukocyte adhesion regulators } \\
\hline \multicolumn{2}{|c|}{ Adhesion stimulants (E-selectin, P-selectin, intercellular adhesion molecule 1 (ICAM-I), vascular cell adhesion molecule 1 (VCAM-I) } \\
\hline \multicolumn{2}{|c|}{ Vascular growth regulators } \\
\hline Stimulants & Inhibitors of myocyte migration and proliferation \\
\hline $\begin{array}{c}\text { Endothelin-I } \\
\text { Angiotensin-II } \\
\text { Superoxide radicals } \\
\text { Growth factors: fibroblast, platelet, insulin-like, } \\
\text { transforming growth factor } \beta \text { (bFGF, PDGF, IGF, TGF } \beta \text { ) }\end{array}$ & $\begin{array}{l}\mathrm{NO} \\
\text { Prostacyclin }\left(\mathrm{PgI}_{2}\right) \\
\text { C-natriuretic peptide }\end{array}$ \\
\hline \multicolumn{2}{|c|}{ Regulators of inflammation, vascular permeability, apoptosis of vascular wall components } \\
\hline \multirow{2}{*}{$\begin{array}{c}\text { Stimulants } \\
\text { Tumor necrosis factor } \alpha(\mathrm{TNF} \alpha) \text { Superoxide radicals }\left(\mathrm{O}_{2}^{-}, \mathrm{OONO}^{-}\right) \\
\text {Protein kinase } \mathrm{C}\end{array}$} & Inhibitors \\
\hline & NO \\
\hline
\end{tabular}

evaluation, since currently they have negative side effects and deliver mediocre results [3]. Physiotherapeutic procedures are one of the options considered when the functional state of the endothelium needs to be normalized [34].

\section{Primary and secondary mechanisms of the biomodulating action of low-level laser therapy (LLLT)}

The current understanding of the biomodulating action of LLLT, which agrees with the clinical practice of laser therapy use, has the thermodynamic triggering of $\mathrm{Ca}^{2+}$ dependent processes as the primary mechanism. Once the various intracellular components have absorbed photon energy (laser light), the intracellular calcium store is activated, $\mathrm{Ca}^{2+}$ ions are released and the concentration in the form of two waves with half periods of 100 and $300 \mathrm{~s}$ is increased, which is followed by the cascade of responses on all levels, from cells to the entire body: activation of mitochondria, cellular metabolism and proliferation, normalization of the immune and vascular systems, inclusion of the autonomic and central nervous system into the process, etc (Fig. 1) [35-37].

Versatility and high efficacy of laser therapy, which is unique type of physiotherapy, relies on the action at cellular level, with the maximum frequency of optical band electromagnetic waves and laser light coherence (monochromaticity).

\section{Influence of LLLT on the vascular homeostasis regulation factors and immunity}

It is well known that almost all of the above regulators (Table 1) are, to a certain degree, associated with changes in $\mathrm{Ca}^{2+}$ concentration; we will cite only a few reviews [38-39].
From the point of view of the subject researched, we should be primarily interested in nitric oxide, the synthesis and release of which is $\mathrm{Ca}^{2+}$ dependent [40]; therefore, it is not surprising that many studies confirm that LLLT can stimulate the release of $\mathrm{NO}$, thus enabling regulation of the vascular homeostasis [41-47].

Moreover, there are studies demonstrating a direct relationship between intracellular $\mathrm{Ca}^{2+}$ concentration increase and NO release intensity and subsequent vasodilation [48-50].

Endothelial system normalization in children with bronchial asthma was confirmed by changes in various parameters of blood plasma, including endothelin-1 and nitric oxide [51-52]. The capacity of LLLT to effectively stimulate the release of PGE has been proven both in experimental [53-55] and clinical studies [56-58].

In arterial hypertension patients, regimens of both external laser therapy (ELT) pulsed infrared LLLT) and intravenous laser blood therapy (IVLBT) improve a number of biochemical, hemorheological and hormonal parameters (C-peptide, insulin, angiotensin, bradykinin, aldosterone, cortisol), and the improvements persist for at least 6 months [59-61].

Many researchers have shown the role of the kallikrein system in hemovascular regulation and the possibility of its correction through illumination of blood with red laser (wavelength of $635 \mathrm{~nm}$ ) and/or incoherent ultraviolet (UV) light [62-65].

Current laser therapy techniques actively exploit the wellknown anti-inflammatory effect of LLLT. Numerous studies have shown that LLLT can activate phagocytes (which absorb foreign particles of bacteria, viruses, and dying cells) and the synthesis of cytokines, including interferons (IFNs), which spearhead the first line of defense against viruses 


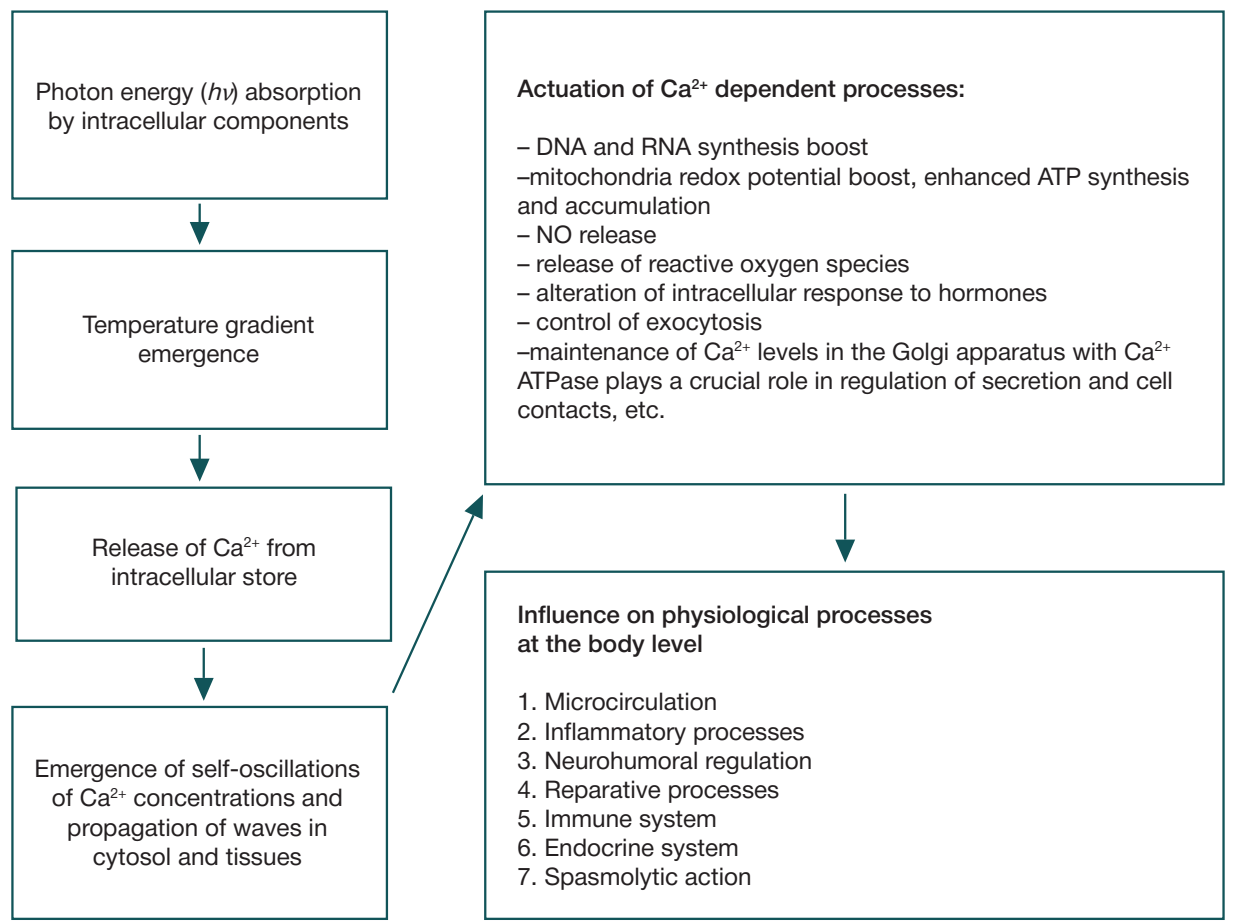

Fig. 1. Molecular-cellular mechanisms of the biomodulating action of LLLT

and contribute greatly to the development of adaptive immunity. IFN $\alpha$ and IFN $\beta$, which are secreted by lymphocytes, macrophages, fibroblasts and some epithelial cells, stimulate the activity of macrophages and natural killer cells (NK). IFN $\gamma$, secreted by T-cells and EK, regulates the immune response, has antiviral and antitumor effects. In addition, LLLT improves micro- and macrocirculation by increasing the saturation of damaged tissues with oxygen and improving their trophic supply by boosting metabolism and proliferation, thus initiating the development of recovery processes. These properties of LLLT make it an effective prevention and therapeutic tool that can be used to counter viral infection and its consequences and to prevent development of pulmonary fibrosis [37].

\section{Laser therapy techniques}

In the context of COVID-19 treatment, external laser therapy or intravenous laser blood illumination (ELD or IVLBT) are used
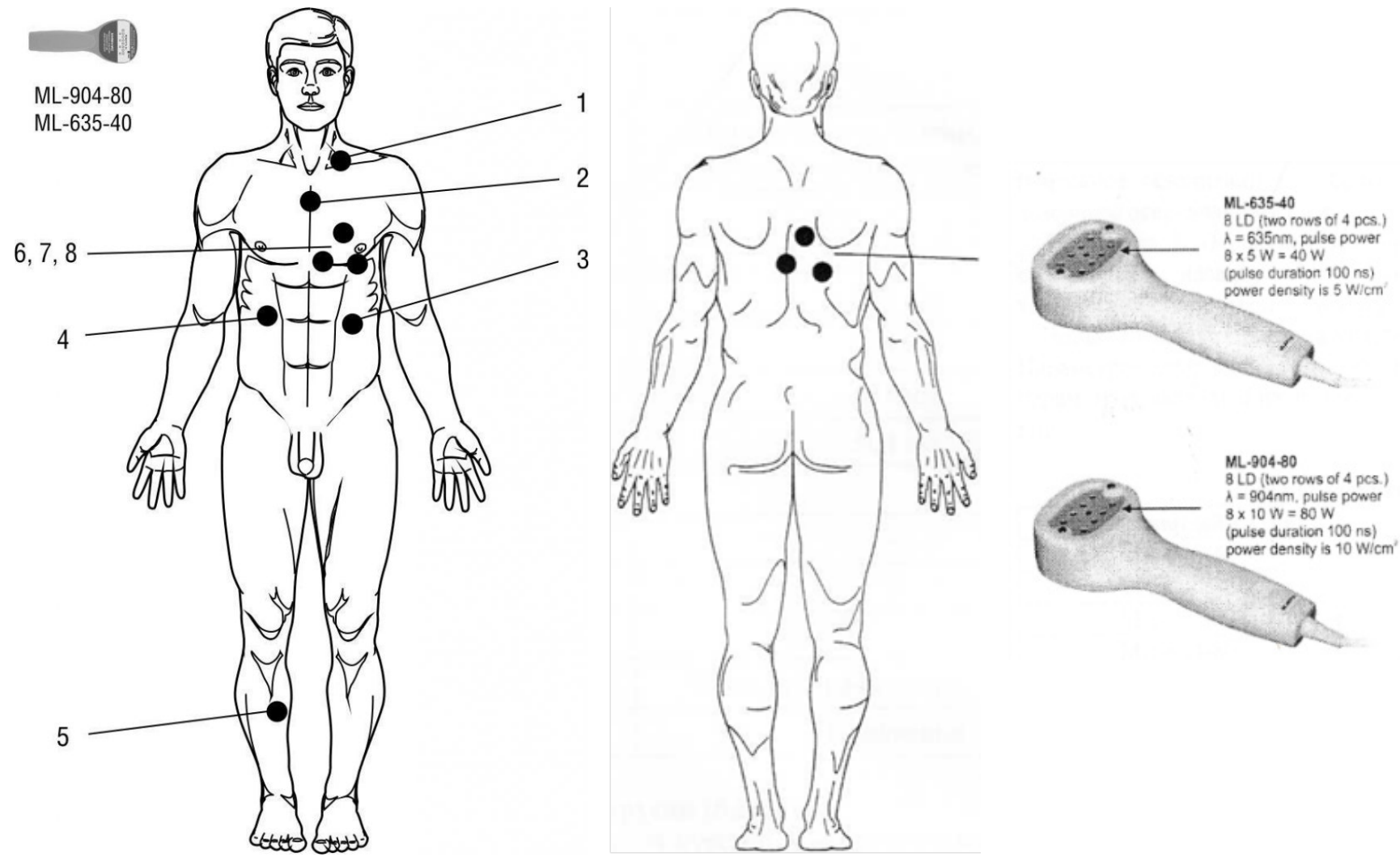

Fig. 2. Zones exposed to laser radiation from the emitting heads 
Table 2. Zones exposed to laser light as a coronavirus disease prevention measure

\begin{tabular}{|l|c|c|}
\hline \multicolumn{1}{|c|}{ Emitting head type } & Exposed area (Figure 2) & Exposure, min \\
\hline ML-635-40 & 1 - left supraclavicular region & 2 \\
\hline ML-904-80 & $2-$ thymus & 1 \\
\hline ML-904-80 & $3-$ spleen & 1 \\
\hline
\end{tabular}

Table 3. Parameters of the LLLT technique for prevention of coronavirus disease

\begin{tabular}{|c|c|c|}
\hline Parameter & Value & Notes \\
\hline \multirow{2}{*}{ Laser light wavelength, $\mathrm{nm}$ (spectrum) } & 635 (red) & \multirow{2}{*}{-} \\
\hline & $904(\mathrm{IR})$ & \\
\hline Laser operating mode & Pulse & Matrix emitting head, surface area $10 \mathrm{~cm}^{2}$ \\
\hline Light pulse duration, ns & $100-150$ & - \\
\hline \multirow{2}{*}{ Radiation power, W } & $35-40$ & $635 \mathrm{~nm}$ \\
\hline & $60-80$ & 904 nm \\
\hline \multirow{2}{*}{ Power density, W/cm² } & $4-5$ & $635 \mathrm{~nm}$ \\
\hline & $8-10$ & 904 nm \\
\hline Frequency, $\mathrm{Hz}$ & 80 & \\
\hline Exposure per zone, min & See table 2 & - \\
\hline Number of exposed zones & 3 & - \\
\hline Localization & See table 2 & - \\
\hline Method & Contact & Through the transparent tip \\
\hline Number of procedures per regimen & $2-3$ & Daily \\
\hline
\end{tabular}

to reach immunocompetent organs and applied locally, to the lesion focus [66]. This approach, a combination of exposure to LLLT on the systemic and local levels, has shown great results in clinical practice [66-69]. The most common technique used for the purpose of endothelium function correction is the "classical" wavelength of $635 \mathrm{~nm}, 2-3 \mathrm{~mW}$ output power and 10-20 min of exposure [70-76]. However, recently a combined version of the technique that includes laser UV blood illumination (LUVBI) has been gaining popularity [77-79]. The specialists are also well aware of the degrees of efficacy achievable in combinations of laser therapy and other physiotherapeutic methods, which have been confirmed in the treatment of COVID-19 [80-82].

\section{LLLR-based coronavirus disease prevention and treatment}

Those who have come into contact with the sick or who have arrived from epidemiologically unsafe areas are prescribed 2-3 LLLT procedures as prevention.

The sick receive treatment in hospitals; the regimen includes 10-12 daily laser therapy procedures.

Two versions of LLLT methods have been developed, the first relying solely on non-invasive techniques (external illumination) and the second, more effective, which involves IVLBT.

Table 4. Zones exposed to laser light in coronavirus patients

\section{Method 1: prevention}

Before starting the procedure, it is necessary to remove the protective cover and mount the magnetostatic field (MF) tip. The tip should be subjected to preliminary chemical sterilization (disinfection).

Fig. 2A and Fig. 2B show the zones (points) of application; Table 2 and Fig. 2C prescribe the type of emitting head and the exposure; Table 3 contains the parameters of the laser light.

\section{Method 1: treatment}

Before starting the procedure, it is necessary to remove the protective cover and mount the MF tip. The tip should be subjected to preliminary chemical sterilization (disinfection).

Fig. 2A and Fig. 2B show the zones (points) of application; Table 4 prescribes the type of emitting head and the exposure. Table 5 contains the parameters of the laser light.

\section{Combined method 2}

Combined method: external irradiation of zones 6-8 as shown on Fig. 2; type of emitting head and exposure as given in Table 4;

\begin{tabular}{|l|c|c|}
\hline \multicolumn{1}{|c|}{ Emitting head type } & Exposed zone (Fig. 1) & Exposure, min \\
\hline ML-635-40 & 1- left supraclavicular region & 1 \\
\hline ML-904-80 & 2- thymus & 1 \\
\hline ML-904-80 & 3- spleen & 2 \\
\hline ML-904-80 & $4-$ liver & 0.5 min per zone \\
\hline ML-635-40 & 5- E36 (zu san li) - symmetrical & 1.5 min per zone \\
\hline ML-904-80 & $\begin{array}{c}\text { 6-8 - lung injury projection } \\
\text { (see Fig. 2 for localization example) }\end{array}$ \\
\hline
\end{tabular}


Table 5. Parameters of the LLLT technique for treatment of coronavirus patients

\begin{tabular}{|c|c|c|}
\hline Parameter & Value & Notes \\
\hline \multirow{2}{*}{ Laser light wavelength, $\mathrm{nm}$ (spectrum) } & 635 (red) & \multirow{2}{*}{-} \\
\hline & 904 (IR) & \\
\hline Laser operating mode & Импульсный & Matrix emitting head, surface area $10 \mathrm{~cm}^{2}$ \\
\hline Light pulse duration, ns & $100-150$ & - \\
\hline \multirow{2}{*}{ Radiation power, W } & $35-40$ & $635 \mathrm{~nm}$ \\
\hline & $60-80$ & $904 \mathrm{~nm}$ \\
\hline \multirow{2}{*}{ Power density, W/cm² } & $4-5$ & $635 \mathrm{~nm}$ \\
\hline & $8-10$ & $904 \mathrm{~nm}$ \\
\hline \multirow[b]{2}{*}{ Frequency, $\mathrm{Hz}$} & 80 & Zones 1-5 \\
\hline & $80-1500$ & $\begin{array}{l}\text { Zones } 6-8 \text {, frequency can be varied depending } \\
\text { on symptoms and patient condition }\end{array}$ \\
\hline Exposure per zone, min & See table 4 & - \\
\hline Number of exposed zones & 8 & - \\
\hline Localization & See table 4 & - \\
\hline Method & Contact & Through the transparent tip \\
\hline Number of procedures per regimen & $10-12$ & Daily \\
\hline
\end{tabular}

aser light parameters as provided in Table 5. Next step: IVLBT-525 + LUVBI (Table 6; Fig. 3).

Thirty-one SARS-CoV2-induced pneumonia patients with comorbidities (CVD, metabolic syndrome, type 2 diabetes mellitus, COPD, etc.) received rehabilitation treatment in the Central Clinical Hospital for the Rehabilitation of FMBA of Russia. In this group, the degree of damage to the lung tissue varied from 25 to $92 \%$. Both of the above laser therapy methods were used for the patients; they delivered good results in the treatment of COVID-19 patients with severe lung lesions.

Subjectively, all patients noted general condition improvement, relief of chest pain associated with coughing, better sputum discharge, less severe shortness of breath. Moreover, in all patients we registered better oxygen saturation (pulse oximetry data) with the mean improvement from 93 to $97 \%$; stabilization of the external respiration function accompanied by the increase of the vital volume of lungs; improvements revealed by the repeated lungs computed tomography. It is important that in the process of rehabilitation, these patients had their psychoemotional status normalized and the number of asthenic and anxiety-depressive incidents decreased (as measured with the Beck Depression Inventory and the MPS test (multilateral personality study).

The use of laser therapy for COVID-19 patients for the first time in the Central Clinical Hospital for the Rehabilitation

Table 6. Parameters of the IVLBT $525+$ LUVBI technique (basic)

Table 6. Parameters of the IVLBT $525+$ LUVBI technique (basic)
\begin{tabular}{|l|c|c|}
\hline \multicolumn{1}{|c|}{ Parameter } & Value & Notes \\
\hline \multirow{2}{*}{ Laser light wavelength, nm (spectrum) } & $365-405$ (UV) & LUVBI \\
\cline { 2 - 3 } & $520-525$ (green) & IVLBT-525 \\
\hline Laser operating mode & Continuous & At the outlet of the disposable light guide \\
\hline Radiation power ${ }^{*}, \mathrm{~mW}$ & $1,5-2$ & LUVBI \\
\hline \multirow{2}{*}{ Exposure, min } & $3-5$ & IVLBT-525 \\
\hline Localization & $7-8$ & $\begin{array}{c}\text { Through the disposable sterile light guide KIVL-01 made } \\
\text { by the Matrix R\&D Center } \\
\text { (TU 9444-005-72085060-2008) }\end{array}$ \\
\hline \multirow{2}{*}{ Method } & Vein ulnar median (v. mediana cubiti) & Intravenously \\
\hline Number of procedures per regimen & $10-12$ & Daily, alternating every other day IVLBT-525 and LUVBI \\
\hline
\end{tabular}

of FMBA of Russia is mentioned as an example of the above promising non-drug therapies. As we gain experience, we shall report clinical data, more widely and in detail, with a statistical analysis of the results, evidence-based conclusions of the effectiveness of the method and personalized approaches in the complex treatment and prevention of complications.

\section{CONCLUSION}

This literature review demonstrates the capacities of laser therapy in the context of endothelial dysfunction treatment. The review cites positive experience of using laser therapy in the complex treatment and rehabilitation of patients with atypical pneumonia caused by various coronaviruses and the new SARS-CoV2.

LLLT is shown an absolutely safe, highly effective, simple and inexpensive method of prevention, treatment and rehabilitation of both chronic non-infectious cardiovascular and pulmonary pathologies and diseases caused by a viral infection, including COVID-19.

To enable personalized approach to rehabilitation of COVID-19 patients, it is necessary to search for informative biomarkers of genetic predisposition to endothelial dysfunction, hemostasis disorders, assess the individual characteristics of 
innate immunity and adaptive immune response to infection, risks of hyperreaction, cytokine storm, multiple organ failure, delayed manifestation of complications in a particular patient. Determination of the contribution of these individual (hereditary and environmental) factors, consideration of their mutual influences are crucial for application of the results of such complex examinations in real practice and indispensable for the development of individual prognosis, prevention (primary and secondary) measures, targeted treatment regimens that, in particular, include LLLT.

\section{References}

1. Pons S, Fodil S, Azoulay E, Zafrani L. The vascular endothelium: the cornerstone of organ dysfunction in severe SARS-CoV-2 infection. Crit Care. 2020; 24 (1): 353. DOI: 10.1186/s13054020-03062-7.

2. Ackermann M, Verleden SE, Kuehnel M, et al. Pulmonary Vascular Endothelialitis, Thrombosis, and Angiogenesis in Covid-19. N Engl J Med. 2020; 383 (2): 120-28. DOI: 10.1056/NEJMoa2015432.

3. Suchkov IA. Korrekcija jendotelial'noj disfunkcii: sovremennoe sostojanie problemy (obzor literatury). Rossijskij medikobiologicheskij vestnik imeni akademika I. P. Pavlova. 2012; 20 (4): 151-57. Russian.

4. Furchgott RF, Zawadzki JV. The obligatory role of endothelial cells in the relaxation of arterial smooth muscle by acetylcholine. Nature. 1980; 288 (5789): 373-76.

5. Aleksandrov AA. Baza znanij po biologii cheloveka. Razdel narushenija funkcii jendotelija i serdechno-sosudistye zabolevanija. Dostupno po ssylke: https://humbio.ru/humbio/car_g/000b1acc. $\mathrm{htm}$. Russian.

6. The Human Genome Project (HGP). Available from: https://www. genome.gov/human-genome-project.

7. The 1000 Genomes Project Consortium. Erratum: A map of human genome variation from population-scale sequencing. Nature. 2011; 473: 544. Available from: https://doi.org/10.1038/ nature09991.

8. O'Donnell CJ, Nabel EG. Genomics of cardiovascular disease. N Engl J Med. 2011; 365 (22): 2098-09. DOI: 10.1056/ NEJMra1105239.

9. Roberts R, Marian AJ, Dandona S, Stewart AF. Genomics in cardiovascular disease. J Am Coll Cardiol. 2013; 61 (20): 202937. DOI: 10.1016/j.jacc.2012.12.054.

10. Online Mendelian Inheritance in Man ${ }^{\circledR}$ An Online Catalog of Human Genes and Genetic Disorders. Available from: https://www. omim.org.

11. The National Center for Biotechnology Information. Available from: https://www.ncbi.nlm.nih.gov/variation/news/NCBI retiring_HapMap.

12. Torshin IYu, Gromova OA. Sosudistye zabolevanija serdca, mozga i molekuljarnye geny. Associativnye issledovanija i patofiziologija sosudistyh zabolevanii. Trudnyj pacient. 2008; 2-3. Available from: https://cyberleninka.ru/article/n/sosudistye-zabolevaniyaserdtsa-mozga-i-molekulyarnye-geny-assotsiativnyeissledovaniya-i-patofiziologiya-sosudistyh-zabolevaniy. Russian.

13. Kirichuk VF, Glybochko PV, Ponomareva Al. Disfunkcija jendotelija. Saratov: Izd-vo Saratovskogo GMU, 2008; 129 s. Russian.

14. Levickij SN. Geneticheskie markery jendotelinovoj sistemy v uspeshnosti vypolnenija kognitivnyh zadach. Dostupno po ssylke: http://scienceforum.ru/2017/article/2017037479. Russian.

15. Moroz W, Smirnova SG, Ivanova OV, Poroshenko GG. Mutacii $i$ antimutageny $\vee$ medicine kriticheskih sostojanij. Obshhaja reanimatologija. 2007; 3 (5-6): 213-7. Russian.

16. Moroz W, Vlasenko AV, Golubev AM, Jakovlev VN, Alekseev VG, Bulatov N. N., Smelaja T. V. Patogenez i differencial'naja diagnostika respiratornogo distress sindroma. Obshhaja reanimatologija. 2011; 7 (3): 5-13. Russian.

17. Moroz VV, Smelaja TV, Golubev AM, Salnikova LE. Genetika i medicina kriticheskih sostojanii: ot teorii k praktike. Obshhaja reanimatologija. 2012; 7 (4): 5-12. Russian.

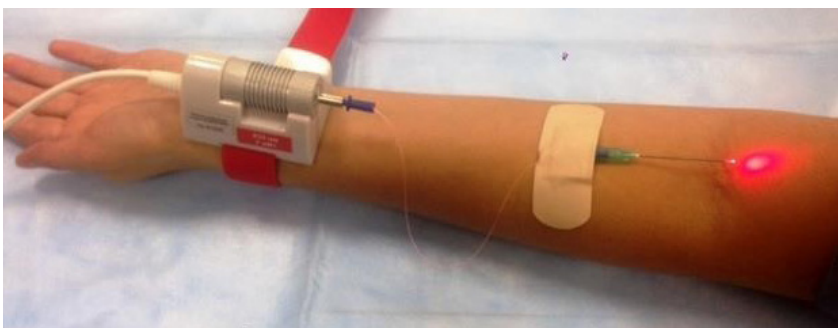

Fig. 3. IVLBT procedure
18. Salnikova LE, Smelaya TV, Moroz W, Golubev AM, Rubanovich AV. Functional polymorphisms in the CYP1A1, ACE, and IL-6 genes contribute to susceptibility to community-acquired and nosocomial pneumonia. International Journal of Infectious Diseases. 2013; Feb 11: 119-24.

19. Nazarenko Gl, Klejmenova EB, Gushhina NN. Izuchenie geneticheskih markerov i tradicionnyh faktorov riska razvitija ishemicheskoj bolezni serdca. Ros. med. vesti. 2009; 14 (1): 47 54. Russian.

20. Genetika cheloveka: test-sistemy dlja PCR-diagnostiki. Katalog produkcii. Nauchno-proizvodstvennaja firma Laboratorija «Liteh». 2020, 38 s. Dostupno po ssylke: http://lytech.ru/upload/medialibrary/ lytpdf/Catalog_genetics_2020_02_26.pdf.

21. Ponomareva NYu, Mitkovskij VG, Jampolskaja EN, Kochetkov AV. Ispol'zovanie innovacionnyh podhodov personificirovanno: mediciny i genotipirovanija $\vee$ medicinskoj reabilitacii. $\vee$ sbornike: Materialy Nauchno-prakticheskoj Konferencii «Aktual'nye voprosy medicinskoj reabilitacii» v MC «Reshma». Nauchno-prakticheskij zhurnal «Kurortnaja medicina». 2016; 2: 119-21. Russian.

22. Ponomareva NYu, Mitkovskij VG, Jampolskaja EN, Kochetkov AV, Nalbandjan N. G. Genotipirovanie kak novoe sredstvo diagnostiki, profilaktiki $\mathrm{i}$ individual'noj terapii narushenij svertyvajushhej sistemy krovi. V sbornike: Materialy 3-go Vsemirnogo Kongressa "Controversies in Thrombosis and Hemostasis (CiTH)" sovmestno s 8-j Vserossijskoj konferenciej po klinicheskoj gemostaziologii : gemoreologii. Tromboz, gemostaz i reologija. M., 2016; 3 (1): 337-38. Russian.

23. Ponomareva NYu, Mitkovskij VG, Jampolskaja EN, Kochetkov AV. Geneticheskie issledovanija dlja mediciny jekstremal'nyh situacij. Medicina jekstremal'nyh situacii. 2017; 4: 63-74. Russian.

24. Ponomareva NYu, Kochetkov AV, Mitkovskij VG, Jampolskaja EN. Integracija personificirovannyh podhodov $v$ praktiku vosstanovitel'noj mediciny: ot diagnostiki k lecheniju i reabilitacii. V sbornike: Materialy III Mezhdunarodnogo kongressa «Fizioterapija. Lechebnaja fizkul'tura. Reabilitacija. Sportivnaja medicina», 2017; 112. Dostupno po ssylke: http://www.rehabcongress.ru. Russian. 25. Ponomareva NYu, Mitkovskij VG, Jampolskaja EN, Kochetkov AV. Geneticheskoe obsledovanie i personificirovannoj podhod $v$ zdorov'esberezhenii, preventivnoj i vosstanovitel'noj medicine. $V$ sbornike: Materialy Konferencii HII Vserossijskogo foruma Vystavki i Kongressa «Zdorov'e nacii — osnova procvetanija Rossii» 2018; 36-43. Russian.

26. Baranov VS. Genom cheloveka, «nedostajushhaja» nasledstvennost' geneticheskij pasport. Medicinskaja genetika. 2011; 9: 3-10.

27. Kolchanov NA, Podkolodnaja AO, Ignateva EV, i dr. Integracija gennyh setej, kontrolirujushhih fiziologicheskie funkcii organizma. Vestnik VOGIS. 2005; 9 (2): 179-199. Russian.

28. Kochetkov AV. Lechebnye fizicheskie faktory na jetape rannej reabilitacii bol'nyh cerebral'nym insul'tom [dissertacija]. M., 1998 Russian.

29. Daulatzai MA. Cerebral hypoperfusion and glucose hypometabolism: Key pathophysiological modulators promote neurodegeneration, cognitive impairment, and Alzheimer's disease. J Neurosci Res. 2017; 95 (4): 943-72. DOI: 10.1002/ jnr.23777.

30. Grigorev NB, Granik VG. Oksid azota (NO). Novyj put' k poisku 
lekarstv. M.: Vuzovskaja kniga, 2004; 360 s. Russian.

31. Krupatkin Al, Sidorov W. Lazernaja dopplerovskaja floumetrija mikrocirkuljacii krovi. M.: Medicina, 2005; 256 s. Russian.

32. Moskvin SV, Ryzhova TV. Lazernaja terapija $\vee$ jendokrinologii. Serija «Jeffektivnaja lazernaja terapija». T. 5. Tver': Triada, 2020; 1024 s. Russian.

33. Brownlee M. The pathobiology of diabetic complications: a unifying mechanism. Diabetes. 2005; 54 (6): 1615-25. DOI: 10.2337/diabetes.54.6.1615

34. Shvalb PG, Kalinin RE, Kachinskij AE. Konservativnoe lechenie zabolevanij perifericheskih sosudov. Rjazan': Poligrafkombinat «Tigel'», 2008; 91 s. Russian.

35. Moskvin SV. Lazernaja terapija v dermatologii: vitiligo. M.: Tehnika, 2003; 125 s. Russian.

36. Moskvin SV. Sistemnyj analiz jeffektivnosti upravlenija biologicheskimi sistemami nizkojenergeticheskim lazernym izlucheniem [dissertacija]. Tula, 2008. Russian.

37. Moskvin SV. Jeffektivnost' lazernoj terapii. Serija «Jeffektivnaja lazernaja terapija». T. 2. Tver': Triada, 2014; 896 s. Russian.

38. Deanfield JE, Halcox JP, Rabelink TJ. Endothelial function and dysfunction: testing and clinical relevance. Circulation. 2007; 115 (10): 1285-95. DOI: 10.1161/CIRCULATIONAHA.106.652859.

39. Shimokawa H. Godo S, Shimokawa H. Divergent roles of endothelial nitric oxide synthases system in maintaining cardiovascular homeostasis. Free Radic Biol Med. 2017; 109: 4-10. DOI: 10.1016/j.freeradbiomed.2016.12.019.

40. Murrey RK, Granner DK, Mayes PA, Rodwell WW. Harper's biochemistry. Appleton \& Lange: 1996, 700 r.

41. Bpill GE, Bpill AG. Guanilatciklaza i NO-sintetaza - vozmozhnye pervichnye akceptory jenergii nizkointensivnogo lazernogo izluchenija. Lazernaja medicina. 1997; 1 (2): 39-42. Russian.

42. Ankri $R$, Friedman $H$, Savion $N$ et al. Visible light induces nitric oxide (NO) formation in sperm and endothelial cells. Lasers in Surgery and Medicine. 2010; 2 (4): 348-52. DOI: 10.1002/ Ism.20849.

43. Dabbous OA, Soliman MM, Mohamed $\mathrm{NH}$, et al. Evaluation of the improvement effect of laser acupuncture biostimulation in asthmatic children by exhaled inflammatory biomarker level of nitric oxide. Lasers in Medical Science. 2017; 32 (1): 53-59. DOI: 10.1007/s10103-016-2082-9

44. Eshaghi E, Sadigh-Eteghad S, Mohaddes G, Rasta SH. Transcranial photobiomodulation prevents anxiety and depression via changing serotonin and nitric oxide levels in brain of depression model mice: A study of three different doses of $810 \mathrm{~nm}$ laser. Lasers in Surgery and Medicine. 2019; 51 (7): 634-42. DOI: 10.1002/lsm.23082.

45. Houreld NN, Sekhejane PR, Abrahamse H. Irradiation at $830 \mathrm{~nm}$ stimulates nitric oxide production and inhibits pro-inflammatory cytokines in diabetic wounded fibroblast cells. Lasers in Surgery and Medicine. 2010; 42 (6): 494-502. DOI: 10.1002/lsm.20812.

46. Karu TI, Pyatibrat LV, Afanasyeva NI. Cellular effects of low power laser therapy can be mediated by nitric oxide. Lasers in Surgery and Medicine. 2005; 36 (4): 307-14. DOI: 10.1002/lsm.20148.

47. Rizzi M, Migliario M, Tonello S, et al. Photobiomodulation induces in vitro re-epithelialization via nitric oxide production. Lasers in Medical Science. 2018; 33 (5): 1003-8. DOI: 10.1007/s10103018-2443-7.

48. Gorshkova OP, Shuvaeva VN, Dvoreckij DP. Reakcii pial'nyh arterial'nyh sosudov na vozdejstvie nizkointensivnogo lazernogo izluchenija sinej i zelenoj oblastej spektra. Regionarnoe krovoobrashhenie i mikrocirkuljacija. 2013; 12 (3): 71-74. DOI: 10.24884/1682-6655-2013-12-3-71-74. Russian.

49. Amaroli A, Benedicenti A, Ferrando S et al. Photobiomodulation by infrared diode laser: effects on intracellular calcium concentration and nitric oxide production of paramecium. Photochemistry and Photobiology. 2016; 92 (6): 854-62. DOI: 10.1111/php.12644.

50. Gorshkova OP, Shuvaeva VN, Dvoretsky DP. Role of nitric oxide in responses of pial arterial vessels to low-intensity red laser irradiation. Bull Exp Biol Med. 2013; 155 (5): 598-600. DOI: 10.1007/s10517-013-2203-4

51. Glazova TG, Ryvkin Al, Pobedinskaja NS, Larjushkina RM. Analiz jeffektivnosti razlichnyh terapevticheskih kompleksov pri bronhial'noj astme u detej. Vestnik Ivanovskoj medicinskoj akademii. 2013; 18 (4): 56-57. Russian.
52. Glazova TG, Ryvkin Al, Larjushkina RM, i dr. Nizkointensivnoe lazernoe izluchenie v reabilitacii detej s bronhial'noj astmoj. Vestnik Ivanovskoj medicinskoj akademii. 2016; 21 (1): 56-60. Russian.

53. Barberis G, Gamron S, Acevedo $G$ et al. In vitro release of prostaglandin E2 after helium-neon laser radiation from synovial tissue in osteoarthritis. Journal of Clinical Laser Medicine \& Surgery. 1995; 13 (4): 263-65. DOI: 10.1089/clm.1995.13.263.

54. Campana VR, Castel A, Vidal AE et al. Prostaglandin E2 in experimental arthritis of rats irradiated with $\mathrm{He}-\mathrm{Ne}$ laser. Journal of Clinical Laser Medicine \& Surgery. 1993; 11 (2): 79-81. DOI: 10.1089/clm.1993.11.79.

55. Kwon $\mathrm{H}$, Lim WB, Kim JS, et al. Effect of $635 \mathrm{~nm}$ irradiation on high glucose-boosted inflammatory responses in LPS-induced MC3T3-E1 cells. Lasers in Medical Science. 2013; 28 (3): 71724. DOI: 10.1007/s10103-012-1122-3.

56. Burduli NM, Tadtaeva DYa. Vlijanie vnutrivennoj lazernoj terapii na dinamiku prostaglandinov E2 i F2a i sostojanie mikrocirkuljacii u bol'nyh, stradajushhih gastrojezofageal'noj refljuksnoj bolezn'ju. Voprosy kurortologii, fizioterapii i LFK. 2012; 6: 17-20. Russian.

57. Zasorina MA. Kombinirovannoe konservativnoe lechenie hronicheskoj kriticheskoj ishemii nizhnih konechnostej v uslovijah neoperabel'nogo porazhenija arterial'nogo rusla [dissertacija]. M., 2005. Russian

58. Ishpahtin Yul. Aktual'nye problemy ginekologii detskogo vozrasta. Vladivostok: Izd-vo Dal'nevost. federal'nogo un-ta, 2015; 216 s. Russian.

59. Krysjuk OB. Personalizirovannaja lazeroterapija bol'nyh gipertonicheskoj bolezn'ju i ishemicheskoj bolezn'ju serdca [dissertacija]. SPb., 2006. Russian.

60. Stupnickij AA. Magnitolazernaja terapija $\vee$ kompleksnom lechenii bol'nyh gipertonicheskoj bolezn'ju [dissertacija]. SPb., 2004. Russian.

61. Chubarova OG. Vlijanie kvinaprila (akkupro) i kvantovoj gemoterapii na klinicheskoe techenie arterial'noj gipertenzii i metabolicheskogo sindroma [dissertacija]. M., 2004. Russian.

62. Zavalej EG. Vlijanie opticheskogo izluchenija ul'trafioletovogo, vidimogo i infrakrasnogo diapazonov na osnovnye komponenty kallikrein-kininovoj sistemy krovi, serotonin, gistamin $v$ dializatah kozhi u bol'nyh hronicheskim bronhitom [dissertacija]. M., 1987. Russian.

63. Nejmark MI, Kalinin AP. Jekstrakorporal'naja gemokorrekcija v jendokrinnoj hirurgii. M.: Medkniga, 2007; 205. Russian.

64. Proskurjakov W. Perekisnoe okislenie lipidov i gemostaz, puti korrekcii ih narushenij u bol'nyh bronhial'noj astmoj [dissertacija]. Perm, 1995; 21. Russian.

65. Chikisheva IV. Jeffektivnost' nizkointensivnogo lazernogo izluchenija u bol'nyh infekcionno-allergicheskoj formoj bronhial'noj astmy [dissertacija]. Harkov, 1987. Russian.

66. Moskvin SV, Ashadulin EV, Kondrateva MS. Opyt primenenija lazernoj terapii $v$ reabilitacii bol'nyh COVID-19. Vestnik novyh medicinskih tehnologij. Jelektronnoe periodicheskoe izdanie. 2020 (4): Publikacija 3-2. Dostupno po ssylke: http://www.medtsu.tula ru/VNMT/Bulletin/E2020-4/3-2.pdf. DOI: 10.24411/2075-40942020-16697. Russian.

67. Ashadulin EV, Konchugova TV, Moskvin SV. Kombinirovannaja lazernaja terapija $v$ lechenii pacientov s troficheskimi jazvami nizhnih konechnostej. Voprosy kurortologii, fizioterapii i LFK. 2018; 95 (6): 27-33. DOI: 10.17116/kurort20189506127. Russian.

68. Kochetkov AV, Moskvin SV. Lazernaja terapija bol'nyh cerebral'nym insul'tom. Tver: Triada, 2004; 51 s. Russian.

69. Kochetkov AV, Moskvin SV, Karneev AN. Lazernaja terapija v nevrologii. Tver: Triada, 2012; 360 s. Russian.

70. Anackaja LN, Goncharova NV, Severin IN, i dr. Vlijanie vnutrivennogo lazernogo obluchenija krovi na uroven cirkulirujushhih jendotelial'nyh kletok-predshestvennic v ostrom periode lakunarnyh infarktov mozga. Izvestija Nacional'noj akademii nauk Belarusi. Serija medicinskih nauk. 2015; 3: 24-29. Russian.

71. Belov W, Harlamova UV. Ocenka vlijanija vnutrivennoj lazeroterapil na biohimicheskie pokazateli, tolerantnost' $\mathrm{k}$ fizicheskoj nagruzke v zavisimosti ot klassa tjazhesti nestabil'noj stenokardii. Vestnik Juzhno-Ural'skogo gosudarstvennogo universiteta. Serija: Obrazovanie, zdravoohranenie, fizicheskaja kul'tura. 2005; 1 (5): 313-15. Russian. 
72. Belov VV, Harlamova UV. Ocenka faktorov jeffektivnosti nizkointensivnogo lazernogo izluchenija u bol'nyh nestabil'noj stenokardiej. Rossijskij kardiologicheskij zhurnal. 2008; 72 (4): 16-19. Russian.

73. Burduli NM, Gireeva EYu. Vlijanie vnutrivennogo lazernogo obluchenija krovi na funkciju jendotelija u bol'nyh stabil'noj stenokardiej. Vestnik novyh medicinskih tehnologij. 2009; 16 (4): 101-02. Russian.

74. Burduli NM, Krifaridi AS. Vlijanie nizkointensivnoj lazernoj terapii na disfunkciju jendotelija u bol'nyh hronicheskimi virusnymi gepatitami. Mezhdunarodnyj zhurnal serdca i sosudistyh zabolevanij. 2014; 2 (3): 11. Russian.

75. Burduli NM, Krifaridi AS, Aksenova IZ. Patogeneticheskie aspekty primenenija lazernogo izluchenija. Nauchnye vedomosti. Serija: Medicina. Farmacija. 2019; 42 (1): 5-12. DOl: 10.18413/20754728-2019-42-1-5-12. Russian.

76. Gireeva EYu. Dinamika pokazatelej gomocisteina, funkcii jendotelija, processov perekisnogo okislenija lipidov i gemostaza u bol'nyh stabil'noj stenokardiej pod vlijaniem nizkointensivnogo lazernogo izluchenija [dissertacija]. Vladikavkaz, 2010; 25 s. Russian.

77. Burduli NM, Gabueva AA. Korrekcija jendotelial'noj disfunkcii u

\section{Литература}

1. Pons S, Fodil S, Azoulay E, Zafrani L. The vascular endothelium: the cornerstone of organ dysfunction in severe SARS-CoV-2 infection. Crit Care. 2020; 24 (1): 353. DOI: 10.1186/s13054020-03062-7.

2. Ackermann M, Verleden SE, Kuehnel M, et al. Pulmonary Vascular Endothelialitis, Thrombosis, and Angiogenesis in Covid-19. N Engl J Med. 2020; 383 (2): 120-28. DOI: 10.1056/NEJMoa2015432.

3. Сучков И. А. Коррекция эндотелиальной дисфункции: современное состояние проблемы (обзор литературы). Российский медико-биологический вестник имени академика И. П. Павлова. 2012; 20 (4): 151-57.

4. Furchgott RF, Zawadzki JV. The obligatory role of endothelial cells in the relaxation of arterial smooth muscle by acetylcholine. Nature. 1980; 288 (5789): 373-76.

5. Александров А. А. База знаний по биологии человека. Раздел нарушения функции эндотелия и сердечно-сосудистые заболевания. Доступно по ссылке: https://humbio.ru/ humbio/car_g/000b1acc.htm.

6. The Human Genome Project (HGP). Available from: https://www. genome.gov/human-genome-project.

7. The 1000 Genomes Project Consortium. Erratum: A map of human genome variation from population-scale sequencing. Nature. 2011; 473: 544. Available from: https://doi.org/10.1038/ nature09991.

8. O'Donnell CJ, Nabel EG. Genomics of cardiovascular disease. N Engl J Med. 2011; 365 (22): 2098-09. DOI: 10.1056/ NEJMra1105239.

9. Roberts R, Marian AJ, Dandona S, Stewart AF. Genomics in cardiovascular disease. J Am Coll Cardiol. 2013; 61 (20): 202937. DOI: 10.1016/j.jacc.2012.12.054.

10. Online Mendelian Inheritance in $\mathrm{Man}^{\circledR}$ An Online Catalog of Human Genes and Genetic Disorders. Available from: https://www.omim.org.

11. The National Center for Biotechnology Information. Available from: https://www.ncbi.nlm.nih.gov/variation/news/NCBI_retiring_HapMap.

12. Торшин И. Ю., Громова О. А. Сосудистые заболевания сердца, мозга и молекулярные гены. Ассоциативные исследования и патофизиология сосудистых заболеваний. Трудный пациент. 2008; 2-3. Available from: https://cyberleninka.ru/article/n/ sosudistye-zabolevaniya-serdtsa-mozga-i-molekulyarnyegeny-assotsiativnye-issledovaniya-i-patofiziologiya-sosudistyhzabolevaniy

13. Киричук В. Ф., Глыбочко П. В., Пономарева А. И. Дисфункция эндотелия. Саратов: Изд-во Саратовского ГМУ, 2008; 129 с.

14. Левицкий С.Н. Генетические маркеры эндотелиновой системы в успешности выполнения когнитивных задач. Доступно по ссылке: http://scienceforum.ru/2017/article/2017037479.

15. Мороз В. В., Смирнова С. Г., Иванова О. В., Порошенко Г. Г. bol'nyh vnebol'nichnoj pnevmoniej s pomoshh'ju nizkointensivnogo lazernogo obluchenija krovi. Pul'monologija. 2015; 25 (2): 196-8. DOI: 10.18093/0869-0189-2015-25-2-196-198. Russian.

78. Moskvin SV, Konchugova TV, Hadarcev AA. Osnovnye terapevticheskie metodiki lazernogo osvechivanija krovi. Voprosy kurortologii, fizioterapii i LFK. 2017; 94 (5): 10-17. DOI: 10.17116/ kurort201794510-17. Russian.

79. Kulova LA, Burduli NM. Vlijanie nizkointensivnogo lazernogo izluchenija na disfunkciju jendotelija i sostojanie mikrocirkuljatornogo rusla u bol'nyh revmatoidnym artritom. Mezhdunarodnyj zhurnal serdca i sosudistyh zabolevanij. 2014; 2 (3): 44-45. Russian.

80. Moskvin SV, Hadarcev AA. KVCh-lazernaja terapija. Tver: Triada, 2016; 168 s. Russian.

81. Mokmeli S, Vetrici M. Low level laser therapy as a modality to attenuate cytokine storm at multiple levels, enhance recovery, and reduce the use of ventilators in COVID-19. Canadian Journal of Respiratory Therapy. 2020; 56: 25-31. DOI: 10.29390/cjit-2019-015

82. Thevarajan I, Nguyen THO, Koutsakos M, et al. Breadth of concomitant immune responses prior to patient recovery: a case report of non-severe COVID-19. Nature Medicine. 2020; DOI: 10.1038/s41591-020-0819-2.

Мутации и антимутагены в медицине критических состояний Общая реаниматология. 2007; 3 (5-6): 213-7.

16. Мороз В. В., Власенко А. В., Голубев А. М., Яковлев В. Н., Алексеев В. Г., Булатов Н. Н., Смелая Т. В. Патогенез и дифференциальная диагностика респираторного дистресс синдрома. Общая реаниматология. 2011; 7 (3): 5-13.

17. Мороз В. В., Смелая Т. В., Голубев А. М., Сальникова Л. Е. Генетика и медицина критических состояний: от теории к практике. Общая реаниматология. 2012; 7 (4): 5-12.

18. Salnikova LE, Smelaya TV, Moroz W, Golubev AM, Rubanovich AV. Functional polymorphisms in the CYP1A1, ACE, and IL-6 genes contribute to susceptibility to community-acquired and nosocomial pneumonia. International Journal of Infectious Diseases. 2013; Feb 11: 119-24.

19. Назаренко Г. И., Клейменова Е. Б., Гущина Н. Н. Изучение генетических маркеров и традиционных факторов риска развития ишемической болезни сердца. Рос. мед. вести. 2009; 14 (1): 47-54.

20. Генетика человека: тест-системы для ПЦР-диагностики. Каталог продукции. Научно-производственная фирма Лаборатория «Литех». 2020, 38 с. Доступно по ссылке: http:// Iytech.ru/upload/medialibrary/lytpdf/Catalog_genetics_2020_02_26.pdf.

21. Пономарева Н. Ю., Митьковский В. Г., Ямпольская Е. Н., Кочетков А. В. Использование инновационных подходов персонифицированной медицины и генотипирования в медицинской реабилитации. В сборнике: Материаль Научно-практической Конференции «Актуальные вопрось медицинской реабилитации» В МЦ «Решма». Научнопрактический журнал «Курортная медицина». 2016; 2: 119-21.

22. Пономарева Н. Ю., Митьковский В. Г., Ямпольская Е. Н., Кочетков А. В., Налбандян Н. Г. Генотипирование как новое средство диагностики, профилактики и индивидуальной терапии нарушений свертывающей системы крови. В сборнике: Материалы 3-го Всемирного Конгресса "Controversies in Thrombosis and Hemostasis (CiTH)" совместно с 8-й Всероссийской конференцией по клинической гемостазиологии и гемореологии. Тромбоз, гемостаз и реология. М., 2016; 3 (1): 337-38

23. Пономарева Н. Ю. Митьковский В. Г., Ямпольская Е. Н., Кочетков А. В. Генетические исследования для медицинь экстремальных ситуаций. Медицина экстремальных ситуаций. 2017; 4: 63-74.

24. Пономарева Н. Ю. Кочетков А. В., Митьковский В. Г., Ямпольская Е. Н. Интеграция персонифицированных подходов в практику восстановительной медицины: от диагностики к лечению и реабилитации. В сборнике: Материалы III Международного конгресса «Физиотерапия 
Лечебная физкультура. Реабилитация. Спортивная медицина», 2017; 112. Доступно по ссылке: http://www.rehabcongress.ru.

25. Пономарева Н. Ю., Митьковский В. Г., Ямпольская Е. Н., Кочетков А. В. Генетическое обследование и персонифицированной подход в здоровьесбережении, превентивной и восстановительной медицине. В сборнике: Материалы Конференции XII Всероссийского форума Выставки и Конгресса «Здоровье нации - основа процветания России» 2018; 36-43.

26. Баранов В. С. Геном человека, «недостающая» наследственность и генетический паспорт. Медицинская генетика. 2011; 9: 3-10.

27. Колчанов Н. А., Подколодная А. О., Игнатьева Е. В. и др. Интеграция генных сетей, контролирующих физиологические функции организма. Вестник ВОГИС. 2005; 9 (2): 179-199.

28. Кочетков А. В. Лечебные физические факторы на этапе ранней реабилитации больных церебральным инсультом [диссертация]. М., 1998.

29. Daulatzai MA. Cerebral hypoperfusion and glucose hypometabolism: Key pathophysiological modulators promote neurodegeneration, cognitive impairment, and Alzheimer's disease. J Neurosci Res. 2017; 95 (4): 943-72. DOI: 10.1002/ jnr.23777.

30. Григорьев Н. Б., Граник В. Г. Оксид азота (NO). Новый путь к поиску лекарств. М.: Вузовская книга, 2004; 360 с.

31. Крупаткин А. И. Сидоров В. В. Лазерная допплеровская флоуметрия микроциркуляции крови. М.: Медицина, 2005; 256 c.

32. Москвин С. В., Рыжова Т. В. Лазерная терапия В эндокринологии. Серия «Эффективная лазерная терапия». Т. 5. Тверь: Триада, 2020; 1024 с.

33. Brownlee M. The pathobiology of diabetic complications: a unifying mechanism. Diabetes. 2005; 54 (6): 1615-25. DOI: 10.2337/diabetes.54.6.1615.

34. Швальб П. Г., Калинин Р. Е., Качинский А. Е. Консервативное лечение заболеваний периферических сосудов. Рязань: Полиграскомбинат «Тигель», 2008; 91 с.

35. Москвин С. В. Лазерная терапия в дерматологии: витилиго. М.: Техника, 2003; 125 с.

36. Москвин С. В. Системный анализ эффективности управления биологическими системами низкоэнергетическим лазерным излучением [диссертация]. Тула, 2008.

37. Москвин С. В. Эффективность лазерной терапии. Серия «Эффективная лазерная терапия». Т. 2. Тверь: Триада, 2014; $896 \mathrm{c}$.

38. Deanfield JE, Halcox JP, Rabelink TJ. Endothelial function and dysfunction: testing and clinical relevance. Circulation. 2007; 115 (10): 1285-95. DOI: 10.1161/CIRCULATIONAHA.106.652859.

39. Shimokawa H. Godo S, Shimokawa H. Divergent roles of endothelial nitric oxide synthases system in maintaining cardiovascular homeostasis. Free Radic Biol Med. 2017; 109: 4-10. DOI: 10.1016/j.freeradbiomed.2016.12.019.

40. Murrey RK, Granner DK, Mayes PA, Rodwell VW. Harper's biochemistry. Appleton \& Lange: 1996, 700 p.

41. Брилль Г. Е., Брилль А. Г. Гуанилатциклаза и NO-синтетаза возможные первичные акцепторы энергии низкоинтенсивного лазерного излучения. Лазерная медицина. 1997; 1 (2): 39-42.

42. Ankri R, Friedman $\mathrm{H}$, Savion $\mathrm{N}$ et al. Visible light induces nitric oxide (NO) formation in sperm and endothelial cells. Lasers in Surgery and Medicine. 2010; 2 (4): 348-52. DOI: 10.1002/ Ism.20849.

43. Dabbous OA, Soliman MM, Mohamed $\mathrm{NH}$, et al. Evaluation of the improvement effect of laser acupuncture biostimulation in asthmatic children by exhaled inflammatory biomarker level of nitric oxide. Lasers in Medical Science. 2017; 32 (1): 53-59. DOI: 10.1007/s10103-016-2082-9.

44. Eshaghi E, Sadigh-Eteghad S, Mohaddes G, Rasta SH. Transcranial photobiomodulation prevents anxiety and depression via changing serotonin and nitric oxide levels in brain of depression model mice: A study of three different doses of $810 \mathrm{~nm}$ laser. Lasers in Surgery and Medicine. 2019; 51 (7): 634-42. DOI: 10.1002/lsm.23082

45. Houreld NN, Sekhejane PR, Abrahamse H. Irradiation at $830 \mathrm{~nm}$ stimulates nitric oxide production and inhibits pro-inflammatory cytokines in diabetic wounded fibroblast cells. Lasers in Surgery and Medicine. 2010; 42 (6): 494-502. DOI: 10.1002/lsm.20812.

46. Karu TI, Pyatibrat LV, Afanasyeva NI. Cellular effects of low power laser therapy can be mediated by nitric oxide. Lasers in Surgery and Medicine. 2005; 36 (4): 307-14. DOI: 10.1002/lsm.20148.

47. Rizzi M, Migliario M, Tonello S, et al. Photobiomodulation induces in vitro re-epithelialization via nitric oxide production. Lasers in Medical Science. 2018; 33 (5): 1003-8. DOI: 10.1007/s10103018-2443-7.

48. Горшкова О. П., Шуваева В. Н., Дворецкий Д. П. Реакции пиальных артериальных сосудов на воздействие низкоинтенсивного лазерного излучения синей и зеленой областей спектра. Регионарное кровообращение и микроциркуляция. 2013; 12 (3): 71-74. DOl: 10.24884/1682-6655-2013-12-3-71-74.

49. Amaroli A, Benedicenti A, Ferrando $S$ et al. Photobiomodulation by infrared diode laser: effects on intracellular calcium concentration and nitric oxide production of paramecium. Photochemistry and Photobiology. 2016; 92 (6): 854-62. DOI: 10.1111/php.12644.

50. Gorshkova OP, Shuvaeva VN, Dvoretsky DP. Role of nitric oxide in responses of pial arterial vessels to low-intensity red laser irradiation. Bull Exp Biol Med. 2013; 155 (5): 598-600. DOl 10.1007/s10517-013-2203-4

51. Глазова Т. Г., Рывкин А. И., Побединская Н. С., Ларюшкина Р. М. Анализ эффективности различных терапевтических комплексов при бронхиальной астме у детей. Вестник Ивановской медицинской академии. 2013; 18 (4): 56-57.

52. Глазова Т. Г., Рывкин А. И., Ларюшкина Р. М. и др. Низкоинтенсивное лазерное излучение в реабилитации детей с бронхиальной астмой. Вестник Ивановской медицинской академии. 2016; 21 (1): 56-60.

53. Barberis G, Gamron S, Acevedo $G$ et al. In vitro release of prostaglandin E2 after helium-neon laser radiation from synovial tissue in osteoarthritis. Journal of Clinical Laser Medicine \& Surgery. 1995; 13 (4): 263-65. DOI: 10.1089/clm.1995.13.263.

54. Campana VR, Castel A, Vidal AE et al. Prostaglandin E2 in experimental arthritis of rats irradiated with He-Ne laser. Journal of Clinical Laser Medicine \& Surgery. 1993; 11 (2): 79-81. DOI: 10.1089/clm.1993.11.79.

55. Kwon H, Lim WB, Kim JS, et al. Effect of $635 \mathrm{~nm}$ irradiation on high glucose-boosted inflammatory responses in LPS-induced MC3T3-E1 cells. Lasers in Medical Science. 2013; 28 (3): 71724. DOI: 10.1007/s10103-012-1122-3.

56. Бурдули Н. М., Тадтаева Д. Я. Влияние внутривенной лазерной терапии на динамику простагландинов E2 и F2a и состояние микроциркуляции у больных, страдающих гастроэзофагеальной рефлюксной болезнью. Вопрось курортологии, физиотерапии и ЛФК. 2012; 6: 17-20.

57. Засорина М. А. Комбинированное консервативное лечение хронической критической ишемии нижних конечностей в условиях неоперабельного поражения артериального русла [диссертация]. М., 2005.

58. Ишпахтин Ю. И. Актуальные проблемы гинекологии детского возраста. Владивосток: Изд-во Дальневост. федерального ун-та, 2015; 216 с

59. Крысюк О. Б. Персонализированная лазеротерапия больных гипертонической болезнью и ишемической болезнью сердца [диссертация]. СПб., 2006.

60. Ступницкий А. А. Магнитолазерная терапия в комплексном лечении больных гипертонической болезнью [диссертация]. СПб., 2004.

61. Чубарова О. Г. Влияние квинаприла (аккупро) и квантовой гемотерапии на клиническое течение артериальной гипертензии и метаболического синдрома [диссертация]. М., 2004.

62. Завалей Е. Г. Влияние оптического излучения ультрасриолетового, видимого и инфракрасного диапазонов на основные компоненты калликреин-кининовой системы крови, серотонин, гистамин в диализатах кожи у больных хроническим бронхитом [диссертация]. М., 1987.

63. Неймарк М. И., Калинин А. П. Экстракорпоральная гемокоррекция в эндокринной хирургии. М.: Медкнига, 2007; 205.

64. Проскуряков В. В. Перекисное окисление липидов и гемостаз, 
пути коррекции их нарушений у больных бронхиальной астмой [диссертация]. Пермь, 1995; 21.

65. Чикишева И. В. Эффективность низкоинтенсивного лазерного излучения у больных инфекционно-аллергической формой бронхиальной астмы [диссертация]. Харьков, 1987.

66. Москвин С. В., Асхадулин Е. В., Кондратьева М.С. Опыт применения лазерной терапии в реабилитации больных COVID-19. Вестник новых медицинских технологий. Электронное периодическое издание. 2020; (4): Публикация 3-2. Доступно по ссылке: http://www.medtsu.tula.ru/VNMT/ Bulletin/E2020-4/3-2.pdf. DOI: 10.24411/2075-4094-202016697.

67. Асхадулин Е. В., Кончугова Т. В., Москвин С. В. Комбинированная лазерная терапия в лечении пациентов с трофическими язвами нижних конечностей. Вопросы курортологии, физиотерапии и ЛФК. 2018; 95 (6): 27-33. DOI: 10.17116/kurort20189506127.

68. Кочетков А. В., Москвин С. В. Лазерная терапия больных церебральным инсультом. Тверь: Триада, 2004; 51 с.

69. Кочетков А. В., Москвин С. В., Карнеев А. Н. Лазерная терапия в неврологии. Тверь: Триада, 2012; 360 с.

70. Анацкая Л. Н., Гончарова Н. В., Северин И. Н. и др. Влияние внутривенного лазерного облучения крови на уровень циркулирующих эндотелиальных клеток-предшественниц в остром периоде лакунарных инфарктов мозга. Известия Национальной академии наук Беларуси. Серия медицинских наук. 2015; 3: 24-29.

71. Белов В. В., Харламова У. В. Оценка влияния внутривенной лазеротерапии на биохимические показатели, толерантность к физической нагрузке в зависимости от класса тяжести нестабильной стенокардии. Вестник Южно-Уральского государственного университета. Серия: Образование, здравоохранение, физическая культура. 2005; 1 (5): 313-15.

72. Белов В. В., Харламова У. В. Оценка факторов эффективности низкоинтенсивного лазерного излучения у больных нестабильной стенокардией. Российский кардиологический журнал. 2008; 72 (4): 16-19.

73. Бурдули Н. М., Гиреева Е. Ю. Влияние внутривенного лазерного облучения крови на функцию эндотелия у больных стабильной стенокардией. Вестник новых медицинских технологий. 2009; 16 (4): 101-02.

74. Бурдули Н. М., Крифариди А. С. Влияние низкоинтенсивной лазерной терапии на дисфункцию эндотелия у больных хроническими вирусными гепатитами. Международный журнал сердца и сосудистых заболеваний. 2014; 2 (3): 11.

75. Бурдули Н. М., Крифариди А. С., Аксенова И. 3. Патогенетические аспекты применения лазерного излучения. Научные ведомости. Серия: Медицина. Фармация. 2019; 42 (1): 5-12. DOI: 10.18413/2075-4728-2019-42-1-5-12.

76. Гиреева Е. Ю. Динамика показателей гомоцистеина, функции эндотелия, процессов перекисного окисления липидов и гемостаза у больных стабильной стенокардией под влиянием низкоинтенсивного лазерного излучения [диссертация]. Владикавказ, 2010; 25 с.

77. Бурдули Н. М., Габуева А. А. Коррекция эндотелиальной дисфункции у больных внебольничной пневмонией с помощью низкоинтенсивного лазерного облучения крови. Пульмонология. 2015; 25 (2): 196-8. DOI: 10.18093/08690189-2015-25-2-196-198.

78. Москвин С. В., Кончугова Т. В., Хадарцев А. А. Основные терапевтические методики лазерного освечивания крови. Вопросы курортологии, физиотерапии и ЛФК. 2017; 94 (5): 10-17. DOI: 10.17116/kurort201794510-17.

79. Кулова Л. А., Бурдули Н. М. Влияние низкоинтенсивного лазерного излучения на дисфункцию эндотелия и состояние микроциркуляторного русла у больных ревматоидным артритом. Международный журнал сердца и сосудистых заболеваний. 2014; 2 (3): 44-45.

80. Москвин С. В., Хадарцев А. А. КВЧ-лазерная терапия. Тверь: Триада, 2016; 168 с

81. Mokmeli S, Vetrici M. Low level laser therapy as a modality to attenuate cytokine storm at multiple levels, enhance recovery, and reduce the use of ventilators in COVID-19. Canadian Journal of Respiratory Therapy. 2020; 56: 25-31. DOI: 10.29390/cjit-2019-015.

82. Thevarajan I, Nguyen THO, Koutsakos M, et al. Breadth of concomitant immune responses prior to patient recovery: a case report of non-severe COVID-19. Nature Medicine. 2020; DOI: 10.1038/s41591-020-0819-2 